\title{
Political Coexistence in the Basque Case: Institutional Action on Violence, Pluralism and Agreements
}

VALERI A VÁZQUEZ GUEVARA*

Vázquez Guevara, V., 2018. Political Coexistence in the Basque Case: Institutional Action on Violence, Pluralism and Agreements. Oñati Socio-legal Series [online], 1093-1119. Received: 21-03-2016; Accepted: 11-05-2018. Available from: https://doi.org/10.35295/osls.iisl/0000-0000-0000-0979

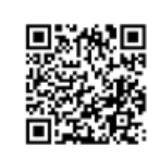

\begin{abstract}
After more than forty years of violent conflict, ETA announced in 2011 the definitive cessation of armed activity in the Basque Country and Spain. The announcement raised questions about how to address the violent legacy of the past in a society characterized by pluralism with a history of opposed political sensibilities, and simultaneously, work towards peaceful coexistence. This article examines how the institutional action of, and in, the Basque regional Government and Parliament shaped "political coexistence" between 2011 and 2015. It uses a content/discourse analysis of three institutional initiatives: Working Group for Peace and Coexistence, Ethical Minimum Agreement, and Plan for Peace and Coexistence. These initiatives formed an institutional framework that opened a small but meaningful public space in Basque political institutions and discourse. The article shows how "political coexistence" within Basque institutions is informed by political parties and groups' experiences, perspectives and positions on violence, pluralism, and agreement/consensus.
\end{abstract}

\section{Key words}

Basque Country; political coexistence; pluralism; political institutions; ETA; peace agreements

\section{Resumen}

ETA anunció en 2011 el cese definitivo de su actividad armada. Surgieron preguntas sobre cómo abordar el legado del pasado violento en una sociedad caracterizada por la pluralidad, con sensibilidades políticas opuestas, y simultáneamente trabajar por la convivencia pacífica. Este artículo examina cómo la acción institucional del Gobierno Vasco y del Parlamento Vasco dio forma a la "convivencia política" entre

\footnotetext{
I would like to thank the two anonymous reviewers for their generous feedback to improve this work, and to Leire Kortabarria for her assistance throughout the publication process. This article draws on my master's thesis at the Oñati IISL in 2015. Completing the master's program was possible with the $2014 / 2015$ scholarship for postgraduate studies awarded by the Department of Education of the Basque Government. To Joxerramon Bengoetxea, Shane Chalmers, Adam Czarnota and Shaun McVeigh: my deepest gratitude for your time, for listening with patience, and helping me to untangle at different stages the thoughts and ideas running through this work.

* Valeria Vázquez Guevara is a doctoral scholar at Melbourne Law School and a member of the Institute for International Law and the Humanities, University of Melbourne (Australia). Contact details. Postal address: Melbourne Law School, 185 Pelham St., Parkville, 3053, VIC (Australia). Email address: v.vazquezguevara@student.unimelb.edu.au. ORCID: https://orcid.org/0000-0001-7774-4882
}

\section{(cc) EY-NC-ND}

Oñati International Institute for the Sociology of Law

Antigua Universidad s/n - Apdo.28 20560 Oñati - Gipuzkoa - Spain

Tel. (+34) 943783064

E: opo@iisj.es W: http://opo.iisj.net 
2011 y 2015. Se examinan tres iniciativas institucionales: Grupo de Trabajo de Paz y Convivencia, Suelo Ético y Plan de Paz y Convivencia. Dichas iniciativas abrieron un pequeño pero significativo espacio público en las en las instituciones y el discurso político vasco. Este artículo demuestra como la "convivencia política" en las instituciones vascas toma forma según la experiencia, perspectiva y posiciones de los partidos y grupos políticos sobre violencia, pluralismo y acuerdos/consensos.

\section{Palabras clave}

Euskadi; convivencia política; pluralismo; instituciones políticas; ETA; acuerdos de paz 


\section{Table of contents / Índice}

1. Introduction 1096

2. After October 2011: Political Reactions, Institutional Action and the Struggle to Work Together....

2.1. Initial political reactions to ETA's 2011 announcement

and Basque society's perceptions between 2011 and 2015

2.2. The Spanish state's legal and political action

3. Basque Political Action: an Institutional Response for Political Coexistence... 1103

3.1. A Political Initiative: the Basque Parliament's Working Group for Peace and Coexistence

3.2. Two Political Documents: The Ethical Minimum Agreement and the Plan for Peace and Coexistence....

4. The Shape of Political Coexistence in the Basque Case.

4.1. Analyzing the Influence of Historical Political Positions

on the Basque Case

4.2. Political Coexistence: Achievements and Challenges on Conceptions of Violence, Pluralism and Agreement

5. Conclusion

References. 


\section{I ntroduction}

In October 2011, the armed group ETA (Euskadi Ta Askatasuna or Basque Country Homeland and Freedom) announced the definitive cessation of armed activity (BBC News 2011). ETA's announcement expressed its firm - and final - unconditional decision to put an end to over forty years of exercising violence in the Basque Country, Spain and I parralde, the French Basque Country. ${ }^{1}$ Although ETA also made political claims over, and conducted violent activity in, I parralde, the 'Basque Case' here refers to the conflict that emerged, developed and escalated mostly under the jurisdiction of the Spanish state. This placed, since the conflict's early stages, primary responsibility on Spain in dealing with, and responding to, ETA's violence and the social, political and legal questions that it raised. ${ }^{2}$ However, the response of the Spanish state towards the violence inflicted by ETA often relied on criminal law. ${ }^{3}$ That position led the Spanish state to overlook possible institutional responses aimed not only at addressing the criminal aspects of ETA's operations, but also at the sociopolitical layers of the conflict. ${ }^{4}$

After ETA's 2011 permanent ceasefire, the question on peaceful coexistence or how to 'live together' became more crucial than ever. For many, especially those living in the Basque Country, an institutional response beyond criminal law was necessary to address the violence of the past in a society characterized by its pluralism with a history of opposed political sensibilities, and simultaneously working towards peaceful coexistence. ${ }^{5}$ In the absence of a desirable legal and political response led by the Spanish state, the Basque Parliament and Government started working on a regional institutional framework to respond to the challenges of coexistence after ETA's 2011 announcement. Yet, Basque political parties and groups faced the challenge of having to work together, despite their opposing political positions and understandings of the conflict, to develop and execute a shared institutional action in the Basque Country.

This article focuses on the institutional challenge within Basque political institutions, to give an institutional answer to questions of peaceful coexistence for the Basque Case in the wake of ETA's 2011 declaration. Specifically, it examines how the institutional action of, and in, the Basque regional Government and Parliament shaped 'political coexistence' between 2011 and 2015. The aim is to provide a deeper understanding of the regional institutional efforts for peaceful coexistence in the Basque Country, as well as the achievements and tensions on understandings of violence, pluralism and agreements. The overarching argument recognizes the importance of giving a legal and political response to a process of peaceful coexistence after violent conflict. However - as I show in this article - this legal and political response to, or institutional action on, how to live together, tends to be conditioned and shaped by 'political coexistence'. As I explain below, I understand 'political coexistence' as a constant process of renegotiating the terms of engagement of a plurality of political groups within political institutions after violent conflict. ${ }^{6}$

\footnotetext{
1 The Basque Country is one of the 17 autonomous regions into which the Spanish state's territorial organization is divided. I parralde is the official name of a French region, popularly known as the Northern or French Basque Country. See the Spanish Constitution (1978), Euskal Kultur Erakundea/Institute Culturel Basque (n.d.).

2 France has actively collaborated and supported the Spanish state in its efforts to weaken ETA, and prosecuted ETA members under French law when they have operated in France. For a brief summary of Spanish-French policing collaborations, see Ollivier-Maurel and Davo 2013.

3 Although jurists, scholars and Spanish criminal law experts agree that the application of criminal law is necessary, many highlight how, in the particular circumstances of the Basque case, is fundamental to complement criminal procedures with restorative justice policies. Furthermore, experts also describe the Spanish state's application of criminal law as 'the criminal law of the enemy'. See generally Bengoetxea 2013, Ezeizabarrena 2013, Bullain 2014.

${ }^{4}$ The case of I nés del Río raised many questions in public opinion about how to accommodate ex-prisoners back in their hometowns after being released from prison, while there exist contradictory narratives about the Basque case; see Burridge 2013.

${ }^{5}$ See note at 4

${ }^{6}$ My theoretical orientation is discussed further below.
} 
In the Basque context, the words 'coexistence' and 'peaceful coexistence' seem to describe an ideal socio-political situation: one in which the historical plurality of Basque society and its multiple political sensibilities and identities are honored and respected. ${ }^{7}$ In the literature on transitional justice, this might describe a situation of 'reconciliation'. However, I use the term 'coexistence', rather than 'reconciliation', for two main reasons. First, the Basque Government and Basque Parliament's groups tend to use the terms 'coexistence' and 'peaceful coexistence' in the public and political discourse (see Bengoetxea 2013 at note 23, p. 56). Second, conversations about 'reconciliation' in the Basque Country tend to be part of the religious discourse or private realm. ${ }^{8}$ As a theoretical matter, the concept of 'political coexistence' also aligns (in ways that 'reconciliation' does not) with Hannah Arendt's theorization of action, plurality and political life in The Human Condition (1958), Jacques Derrida's 'coup de force' in The Force of Law (1989-90), and Andrew Schaap's political theory about 'the talks of reconciliation' in politics in Political Reconciliation (2005). The importance of this will become evident from the analysis of the Basque case. However, to set the stage for that analysis, it is necessary to briefly explain how Arendt, Derrida and Schaap help to understand questions of 'political coexistence'. ${ }^{9}$

In Arendt's and Schaap's thought, political life shapes our understanding of past experiences and our expectations about the future. According to Arendt, humans have the inherent ability to create new things, which she calls 'the human condition of work' or 'worldliness' (Arendt 1958, 150). Importantly, however, a human cannot create new things alone as she/he is conditioned by the human condition of 'action', which is the condition of living in plurality (Arendt 1958, 8). ${ }^{10}$ Arendt points out that the condition of plurality is the condition of all political life, because it moves us to interact with each other (Arendt 1958, 175). At the same time, although we are all human beings, everyone is to an extent unique, or has singular qualities (Arendt 1958,176 ). It is this difference (and hence plurality) that compels us to engage with each other. Schaap's theory of political reconciliation develops this point about the complex dynamics taking place in political life. Schaap's work highlights how politics within political institutions provides a space to contest and express different experiences of a violent past (Schaap 2005, 56). For Schaap, this political contestation is an opportunity to transform individual stories into collective ones (Schaap 2005, 56-57). The outcome of contesting subjective experiences within a public space or public institution shapes and discloses a vision of community.

This 'community' has the potential not only to contain a plurality of visions and experiences, but also to generate risks through the processes of political engagement. That is, on one hand it would be impossible to unify positions that are historically antagonistic, even more so when the differences have been reinforced through violence with the aim to achieve power and a dominant position. On the other hand, this political engagement can give rise to new conflicts, or revive old ones previously channeled through violence. Derrida (1989-1990, 27, 43) calls that tendency 'iterability'; Arendt (1958, 138-139), 'preservation'; and Schaap (2005, 13), 'reaffirmation'. The common point is that political engagement with those considered 'the other' carries the risk of a 'future that can always reproduce the present' (Derrida 1989-1990, 27). Yet, for Arendt and Schaap, and especially for

\footnotetext{
7 This is further developed and explained in this article's conclusions.

8 The public conversation on 'reconciliation' emerged through the voice of the Basque Catholic priest, Monsignor Uriarte. Nonetheless, both words - 'coexistence' and 'reconciliation' - seem to denote a desire to 'live together' peacefully after violent conflict. See Uriarte 2013.

9 This larger theoretical discussion is developed in the author's master's thesis, on which this article builds on. It is available upon request to the author or, at the Library of the International Institute for the Sociology of Law. See, Vázquez Guevara 2015.

${ }^{10}$ Arendt explains her theorization of 'plurality' at length in Chapter V: Action (Arendt 1958, pp. 178-247). Arendt argues that because we are different we can create a world together, insisting that through the preservation of plurality we can build a world together. Otherwise, attempting to homogenize could lead to tyranny, understood as an effort to eradicate the uniqueness of each human being, imposing 'one' way of 'being'.
} 
Derrida, beginnings entail a coup de force. This coup de force, or 'plural force' (Derrida 1989-1990,13), is needed to break with a previous structure instituted or founded with similar force, and avoid returning to previous patterns of hostile interactions and political actions. That is, a coup de force is a disruptive force that removes hostile forms of engagement within a political space, and opens the possibility to constantly reaffirm new forms of plural institutional engagement and action.

Creating an inclusive political space after violent conflict, and preventing the previous hostile order from returning, would require an institutional act to create and sustain a shared political space. Institutions, and law as the material expression of political action, could provide a structure-legal and institutional-for peaceful coexistence. Nonetheless, this requires political groups to accept the plurality of, and often violently opposed, experiences as fundamental to the creation of a common political space. Moreover, they would have to accept this space as one in which these differences are constantly contested (Schaap 2005, 4). In this sense, 'peaceful coexistence' is not a political and legal project aimed at restoring 'friendliness and harmony'. Rather it is a political-legal action, involving a constant process of working together in plurality, and creating and sustaining that institutional and political space, without seeking to overcome the differences.

In sum, what Arendt, Derrida, and Schaap each show in their work on 'coexistence' in an institutional or political context is the importance of a plurality of political agents working together to provide a legal and political response to peaceful coexistence. Or as I show in my analysis of the Basque case, 'political coexistence' is not only about agreement-making between antagonistic groups in a specific time and place, but it is also a constant process of working together, embracing the inherent plurality of life in community. Unlike other process that have aimed at bringing about peaceful coexistence or reconciliation (as in South Africa, Northern Ireland or El Salvador), ${ }^{11}$ the Basque case involves a process developed in a political horizon, where the political and legal initiative for agreement-making was not available for the Basque regional institutions. ${ }^{12}$ Basque political institutions did not have legal authority to settle a political agreement with ETA. Rather, the Spanish Government and Congress had the legal and political authority to respond to the 2011 announcement. ${ }^{13}$ However, Basque political institutions are legally and politically authorized, under Spanish legislation, to undertake institutional actions that could give a political response - without legal form - to the challenge of peaceful coexistence in the Basque Country after ETA's 2011 announcement. ${ }^{14}$

In the remaining parts of the article I analyze the institutional framework or institutional response developed by, and in, Basque political institutions between

\footnotetext{
${ }^{11}$ See the following general references: Whitfield (2014, pp. 9 and 78) provides a brief discussion of these cases in respect to the Basque case. For South Africa see Wilson (2001). For Northern Ireland see Conciliation Resources (2009). For El Salvador see Negroponte (2012).

12 See Bengoetxea's discussion on what he refers as 'soft-law' possibilities for the Basque Case, in Bengoetxea 2013, 47.

${ }_{13}$ During the Spanish Transition to democracy, the 'regional autonomic system' was designed as a complex and hybrid system between federalism and a centralized territorial organization. This system was created as a way to respond to the so-called 'territorial problem' by regulating the relationship between the state and the regional governments, as well as to determine and distribute their legal and executive powers. See, Part VIII, Territorial Organization of the State, esp. articles 143-158 of The Spanish Constitution (1978).

${ }_{14}$ In the Spanish regional autonomic system or territorial organization of the state (see, supra note 14)the regional/autonomous governments and parliaments, like the Basque Government and Parliament, can draft and enforce regional laws, regulation and policies on certain issues. The Autonomous Community's authority on legal and political actions of self-government emanate from the Spanish state's sovereignty and authority. These issues are established in each Autonomous Community's Statute of Autonomy, prior approval by the Spanish Congress and Senate. Within this scheme, the Spanish State has the authority and jurisdiction to negotiate the dismantling of ETA as well as give legal and political form to the reinsertion of ETA members. The Basque regional Government and Parliament can, however, within that framework, undertake institutional or political action toward the Basque Case, according to what is established in the Basque Statute of Autonomy (Ley Orgánica 3/1979).
} 
2011-2015. This framework is made up of one institutional initiative - the Working Group for Peace and Coexistence - and two political documents - the Ethical Minimum Agreement (Suelo Ético, 2013) and the Plan for Peace and Coexistence (Plan de Paz y Convivencia 2013-16). I will do this through a content/discourse analysis. This method considers 'texts' as unit of analysis, and examines the social, political, historical, and cultural contexts in which these texts were produced (Churchill 2013, 255). Through a selection of key theory-driven 'political coexistence' concepts, I interpret the content of the documents. ${ }^{15}$ The analysis shows how 'political coexistence' within Basque institutions is informed by political parties and groups' different experiences, perspectives and positions on violence, pluralism, and the agreement over the Basque case. The conclusion I draw from this is that 'political coexistence' was and is fundamental to develop, shape and sustain an institutional and political response to peaceful coexistence in the Basque Country.

The article is divided into three parts. Part 2 offers an account of how Basque and Spanish political parties and groups struggled to work together immediately after ETA's 2011 announcement, focusing in particular on the political reactions and institutional actions. Part 3 considers how political groups and parties within Basque political institutions started a process for 'political coexistence'. In doing so, this part pays close attention to how Basque political institutions responses' were informed by the Working Group for Peace and Coexistence, the Ethical Minimum Agreement, and the Plan for Peace and Coexistence. Part 4 then examines how the institutional action of, and in, the Basque regional Government and Parliament shaped 'political coexistence' between 2011 and 2015. The focus in this final part is on how the historical past of each political party and group has influenced their forms of political engagement or 'political coexistence'. Again, the analysis is based on a close reading of the texts that form the Basque institutional action for peaceful coexistence: the Working Group for Peace and Coexistence, the Ethical Minimum Agreement, and the Plan for Peace and Coexistence.

\section{After October 2011: Political Reactions, Institutional Action and the Struggle to Work Together}

This section examines the different political reactions to ETA's 2011 announcement of a permanent ceasefire, and the incipient political actions or responses to move toward peaceful coexistence. The section focuses in particular on the position of the Spanish Government and its use of law in its discourse to frame the Basque case. The aim here is to provide an overview of the Basque case that shows the complex political dynamics in Basque political institutions and their relationship with the Spanish state, as well as the significance of their political action between 2011 and late 2015 (the post-2011 announcement period).

\subsection{Initial political reactions to ETA's 2011 announcement and Basque society's} perceptions between 2011 and 2015

'Long live the free Euskal Herria, Long live Basque socialism, no rest until independence and socialism' (BBC News 2011). With those words ETA concluded its October 2011 announcement. However, this was not the first time that ETA made similar 'permanent' ceasefire declarations. In 2006, and in January 2011, ETA announced ceasefires, but as soon as the Spanish government did not fulfill certain demands, ETA resumed armed activity. ${ }^{16}$ With those precedents, politicians, civil

\footnotetext{
15 The three codebooks developed for the content/discourse analysis are on file with the author, and are available upon request, or through the Library of the International Institute for the Sociology of Law. See, Vázquez Guevara 2015.

${ }^{16}$ In the Anoeta Proposal (2004) for the first time Batasuna and its supporters expressed their preference for peace over violence; see Agencias 2004. First permanent ceasefire announcement in 2006, see Tremlett 2006. Second ceasefire announcement in 2010, see BBC News 2010. In 1989 ETA declared a temporal ceasefire during negotiations known, in Spanish, as Mesa de Argel, or in English, Algiers Table. See Whitfield 2015.
} 
society organizations and public opinion considered ETA's 2011 announcement important but insufficient. The Spanish prime minister in 2011, José Luis Rodríguez Zapatero, said that the announcement represented the 'victory of democracy, law and reason' (Rodríguez Zapatero 2011; author's translation), but emphasized: '[W]e expect from ETA a communiqué regarding its definitive dissolution' (RTVE 2011; author's translation), and not one just about 'the definitive cessation of armed activity' (BBC News 2011). Mariano Rajoy, then leader of the main political party in opposition, the conservative People's Party, considered that the announcement was 'good news' and 'an important step' (Rajoy 2011), but what was needed was 'the irreversible dissolution and total dismantling of ETA' (Ibidem). These positions expressed a skepticism of, and call for caution towards ETA's announcement amongst Spanish politicians.

In the Basque Country, the announcement was generally received with a hopeful spirit, based on a perception that it opened a new and more hopeful time for the Basque people and political life. Yet, many remarked that ETA would have to take more steps and fully dismantle. As the socialist Patxi López, then president of the Basque regional Government or lehendakari, put it: 'A new time to overcome the terrorist cycle has begun in Euskadi, our homeland. This is our opportunity for unity and coexistence' (EITB 2011; author's translation) While the leader of the Basque Nationalist Party, soon-to-be elected lehendakari, Íñigo Urkullu, described the moment as 'transcendental' (Urkullu 2011; author's translation), and ETA's announcement as 'great news' because 'the definitive renunciation to the exercise of violence must give way to a lasting peace in the Basque Country. A peace, in which reconciliation and concord can shed light on a new time' (I bidem). Antonio Basagoiti, leader of the Basque People's Party, joined the Basque general political opinion in stating that the announcement was good news. However, Basagoiti emphasized that there was still a long road ahead, and that 'those of us who have been working for freedom have to continue doing it until [ETA] hands over the weapons' (Europa Press 2011). Basque pro-independence left-wing groups, known as 'izquierda abertzale', considered the announcement 'historic', and stressed that 'the closure of ETA's armed-activity cycle does not mean the end of the political conflict' (Ormazabal 2011). Overall, these public political reactions to the announcement acknowledged that a new and hopeful period to live together without violence in the Basque Country had begun. Nonetheless, they all called for caution and emphasized that there would be work to do to realize peaceful coexistence, and stated - with the exception of the izquierda abertzale - that part of that work would require ETA to dismantle.

According to a poll conducted in November and December, after the ceasefire, by the University of the Basque Country's Euskobarómetro, $54 \%$ of the people living in the Basque Country considered the declaration 'insufficient' (Euskobarómetro 2011, 56, para. 1). Yet, $46 \%$ believed that ETA's announcement expressed a sincere will to finally put an end to violent activities (Euskobarómetro 2011, 55). However, three years later, on November 2014, Basques slightly but significantly changed their expectations towards the political implications of ETA's 2011 permanent ceasefire. $61 \%$ rejected ETA (Euskobarómetro 2014, 62), while $46 \%$ did not believe ETA's commitment to end its armed activity (Euskobarómetro 2014). Public support for negotiations with ETA under the condition of its prior dismantling decreased to $33 \%$ compared to 44\% in 2011 (Euskobarómetro 2011, 63), while 50\% were favorable to talks without prior dismantling (Ibid.). Regarding political relationships between political parties and groups, $45 \%$ considered that socio-political tensions in the Basque Country had increased (Euskobarómetro 2011, 30). ${ }^{17}$ On November 2014, three years after the ceasefire, the expectation of a more peaceful social and political life remained divided (see for example, Euskobarómetro 2014, 59). As Euskobarómetro, in its own analysis of the data, concluded: 'the Basque society is little inclined to forgiveness and reintegration' (Euskobarómetro 2014, 63).

\footnotetext{
17 This was not only due do ETA's ceasefire, but also the economic crisis.
} 
These perceptions point to two unvarying expectations in 2011 and 2014 of Basque people toward political groups and ETA: (1) a rejection of violence and a hope that ETA would not return to armed activity; and (2) a desire for a joint intervention of political parties to resolve the conflict after the 2011 announcement. In particular, 'confidence' significantly changed toward the key actors in the conflict, that is, ETA, the Spanish State, and Basque political institutions and parties. There was a latent perception of division amongst these key actors, which were considered to have the power to lead the conflict to a peaceful resolution. However, according to the Euskobarómetro, Basque society considered that conceptions of reconciliation and forgiveness were not only a private or personal matter, but were also an institutional or public issue (see, Euskobarómetro, 2014, 63-64). By 2015 ETA had not committed any violent acts, but it had not dismantled either. With $42 \%$ of Basque society supporting unconditional negotiations, the perception seemed to be that the 2011 announcement was a meaningful commitment and a necessary step toward ETA's disarmament and dissolution (Euskobarómetro 2014, 63). Furthermore, 50\% considered that every ETA member who had been imprisoned, and who individually repented and expressed her/his decision to abandon armed activity, should benefit from social reintegration policies (Ibid.). The institutional dimension of this 'forgiveness' was three-fold. One, there should be social reintegration policies for repentant ETA prisoners. Two, the repentance should be public, and should take the form of an apology to the victims. And three, a form institutional collective memory should be created to acknowledge the suffering caused to victims and their families.

However, expectations that political parties and groups would work together to give an institutional response to a violence-free Basque Country were not high. By 2015, $63 \%$ believed that political relationships within Basque institutions had improved (Euskobarómetro 2015, 20). Yet, 79\% remained pessimistic about political relationships in the Spanish political institutions (Ibid.). In this context, and with a change in the Spanish Government and Parliament, it seemed unlikely that the Spanish state would develop an institutional response, beyond the use of criminal law.

\subsection{The Spanish state's legal and political action}

The skepticism regarding the possibility of joint political action beyond a criminal law response was nourished by the lack of initiative from the Spanish Government. Two months after ETA's October 2011 announcement, the conservative People's Party won Spain's general elections, and Mariano Rajoy became prime minister (Govan 2011). Unlike the previous prime minister, José Luis Rodríguez Zapatero - who endorsed peace negotiations with ETA -, Rajoy and his party's position was: 'we do not negotiate with terrorists' (see for example, Agencias 2011). Their victory in the 2011 general elections reinforced in Spain's politics and institutions a hardline position toward an institutional response to peaceful coexistence in the Basque Country and Spain.

Between 2011 and 2015, that hardline position did not change despite one political initiative for victims of terrorism, as I discuss below. Whenever civil society groups and Basque politicians pressed the Spanish Government, the most common response was to invoke 'the law'. Framing the situation as a matter of crime (terrorism) denied the existence of a political conflict and therefore the need for a peace process (see for example, Montesinos 2013, EFE 2013b). For example, during the 2015 Debate on the State of the Nation, Aitor Esteban, a Basque congressman in the Spanish Congress of Deputies, demanded that Rajoy change his government's policies toward ETA prisoners, especially the 'dispersion policy'. Esteban argued that 'circumstances have changed, thus, policies must change (...) peace is more than the absence of violence' (Cruz 2015). In response, Rajoy replied: '[W]e will continue to apply the dispersion policy until ETA dismantles. There is no reason to change' (Segovia 2015). This response not only illustrates the position of the Spanish Government after the 2011 announcement, but also its failure to undertake an institutional action to 
achieve more than secure party-political interests. In the current political life of the Spanish Congress, key actors - mainly the Spanish Government - suggest that it is ETA's responsibility to move things forward after their 2011 announcement. Until 2015 not every party in the conflict was willing to work with its 'other' on joint institutional actions.

That hardline position, and strict refusal to engage, has increased the risk of 'juridifying' the Basque Case. In Teubner's terms, this is the risk of consolidating an excess of state laws, which would disrupt freedom and a meaningful life (M. Ramstedt at a lecture at the International Institute for the Sociology of Law in 2015). ${ }^{18}$ In this case, law and institutions would lose their potential to balance the particular and collective interests inherent to political life. Law progressively becomes an instrument of politics founded on particular interests. Law is used as a shield to those who hold power to provide political and legal responses to their particular interests. By contrast, law and law-making can be an inclusive force to facilitate the development of the peace process if, within the existing political and legal spaces established by the 1978 Constitution and the Basque Statute of Autonomy, the Basque case issues are publicly embraced with the political disposition to find responses that foster plurality (Czarnota 2001, 122-123).

The question was not only what was expected from ETA, as if the armed group is the only group that society expects to take steps towards peaceful coexistence. The question was also, what can Spanish and Basque institutions do? Those who hold political positions within Spanish and Basque institutions had the possibility to negotiate, to provide an institutional response to the Basque Case. This exercise was a crucial aspect of institutional action as it is conditioned by the inherent plurality of political life. That is, without multilateral conversations and interactions, contestation of subjectivities and a commitment to respect plurality, it would be impossible to create and sustain inclusive public institutions that are representative and responsive to peoples' expectations.

The rocky political relationship with Spain's political institutions, and the static position of the Spanish Government regarding the Basque Case, is reflected not only in its discourse, but also in the lack of political will and initiative to develop policy or legislation to institutionalize a new time of socio-political relationships after the 2011 ceasefire. For example, to date, there is only one state law on victims of terrorism (Ley 29/2011, de 22 de septiembre, de Reconocimiento y Protección Integral a las víctimas de terrorismo, hereinafter Ley 29/2011). This law was enacted before the ceasefire and does not include victims from different sources of violence related to the Basque Case (GAL, security forces, Batallón Vasco-Español, and other extreme right-wing groups). It should be noted that the Ley 29/2011 established the foundation of the Centro Memorial para las Víctimas del Terrorismo (Memorial Center for Victims of Terrorism) [see La Moncloa 2015]. A commission with delegates of both the Spanish and Basque Government was established to develop the institutional design of the Memorial Center (Ministerio del Interior y Departamento de Interior del Gobierno Vasco 2012). Three years later, in January 2015, the Commission made public the final institutional design for the Memorial Center, and in March 2015 Spanish Prime Minister Rajoy inaugurated the Center in Vitoria-Gasteiz, the Basque capital city (Informe de la Comisión de Expertos para la definición del Centro Memorial de las Víctimas del Terrorismo, 2015). The lehendakari, íñigo Urkullu, and representatives of political parties and victims associations, also attended the event. The atmosphere of institutional collaboration was reinforced by the express reference, in both the Basque Government's Plan for Peace and Coexistence and the Memorial Center's institutional design documents, to collaborate with each other and with the Basque Parliament.

${ }^{18}$ This was a lecture given in 2015 by Dr. Martin Ramstedt on The Process of J uridification in the Globalizing World as part of the Law and Anthropology course at the International Institute for the Sociology of Law. 
However, the institutional collaboration and unity was superficial (Domaika 2015). The Basque Government and most of the Basque Parliament's political groups considered that the Spanish Government had sped-up the Memorial Center's inauguration in 2015 to gain more votes in the upcoming 2016 general elections (EFE 2015, Europa Press 2015). While representatives of the Basque Nationalist Party (the party in the Basque Government) did not attend the inaugural event, the leader of the Basque People's Party, Arantza Quiroga, said that the lehendakari - who is part of the Basque Nationalist Party - was 'posing' at the event (Quiroga 2015). Quiroga also added that the Basque Government, despite taking part in the Commission and the lehendakari being the Memorial Center's vice-president, did not support the social and political value of the Memorial Center because of how the inauguration was conducted (Ibid.). In parallel to the joint preparations for the Memorial Center, in November 2014 the Basque Parliament (in which the Basque People's Party became a minority group after the most recent regional elections) approved the creation of their own Institute for Memory, Coexistence and Human Rights. ${ }^{19}$ Yet, its creation was only approved after a long process - from mid-2013 to November 2014 - with 42 votes in favor, 11 against, and 22 abstentions (Ley 4/2014).

What the overlap of these initiatives and the cross-accusations shows is how attempts to work together on joint institutional action with opposite groups requires not only specific institutional action on an issue, but also a conversation about the grounds of engagement within political institutions. This political conversation in the Basque Case has not taken place within Spanish political institutions, but it has, to an extent, in Basque ones. Despite deep tensions within Basque political institutions, the members of the Basque Parliament and Government have taken decisions to reconfigure, within the existing political-legal spaces, their grounds for political engagement, as I now turn to discuss.

\section{Basque Political Action: an Institutional Response for Political Coexistence}

In this section I consider how political groups and parties within Basque political institutions started a process for 'political coexistence'. I argue that the process of political coexistence emerged out of the need to develop an institutional response to the political space that was opened by ETA's 2011 announcement of a permanent ceasefire. This institutional response to the form of a political initiative, the Working Group for Peace and Coexistence, and two political documents: the Ethical Minimum Agreement and the Plan for Peace and Coexistence. This section aims to provide an analysis of how the political engagement of the different political parties and groups in the Basque institutional response was conditioned by each group's particular experiences in the conflict.

\subsection{A Political Initiative: the Basque Parliament's Working Group for Peace and Coexistence}

After the 2009 Basque regional elections for Parliament and Government, the Basque Socialist Party and the Basque People's Party signed a political agreement called Grounds for Democratic Change at the Service of Basque Society (hereinafter, Grounds for Democratic Change; see PSE-EE and PP-PV 2009). Even though the Basque Nationalist Party had won the most votes, winning thirty seats (Gobierno Vasco 2011b), the Grounds for Democratic Change political agreement created a new coalition between the Basque Socialist Party and Basque People's Party that removed the Basque Nationalist Party from the Basque Government for the first time in almost thirty years. ${ }^{20}$ On November 2011, after the ceasefire declaration, 59\% of Basques

\footnotetext{
19 The regional Institute for Memory, Coexistence and Human Rights was approved by the Basque Autonomous Community's law: Ley 4/2014.

20 The Spanish electoral system allows 'governability agreements'. That is, political parties can negotiate who will be in office after elections, which is not necessarily the most voted one. This means that the new prime minister is not directly elected by citizens but through citizens' representatives at the Congress.
} 
considered that the agreement between the Basque Socialist Party and Basque People's Party was essential to end the violent conflict after ETA's announcement (Euskobarómetro 2011, 61). Yet, historical discrepancies and the mismanagement of the Spanish financial crisis by the Socialist Party strained the relationship between the Basque Socialist Party and Basque People's Party in both the Spanish and Basque political institutions. That ultimately led to the termination of the agreement in 2012.

Even with the political alliance between the Basque Socialist Party and Basque People's Party unravelling, Basque nationalist groups struggled to influence policy and law-making decisions in the Basque Parliament. However, new pro-independence left-wing Basque nationalist groups were progressively gaining more parliamentary representation after each election (for example, EH Bildu and Sortu), making them key actors in shaping political coexistence after ETA's 2011 announcement. One of these key actors was Aralar, a Basque pro-independence left-wing party, which increased its representatives from one (in 2005) to four (in 2009) parliamentary representatives.

In February 2012, Aralar's parliamentary spokesperson, Aintzane Ezenarro, presented a motion to urge the Parliament to 'debate in the next plenary session on joint projects for peace and coexistence' [Relativa a los proyectos de construcción conjunta de la paz (admisión a trámite), at Ezenarro 2012; author's translation]. In response to Ezenarro's call, the lehendakari - the socialist Patxi López - participated in a special session at the Basque Parliament to debate 'the management of the end of ETA and measures to address a new time' (Comparecencia del lehendakari para valorar el acuerdo mayoritario 2012, p. 4). It is in that special parliamentary session that Aralar's proposal was characterized as a 'special working group for coexistence' (Id., p. 28). Regarding the proposed Working Group, the lehendakari stressed that it should be a space 'to make and consent to political initiatives that would help us to accelerate the definitive end of terrorism and the consolidation of peace for everyone' (Id., p. 8). That is, the lehendakari suggested that the working group represented a new space for discussion and analysis, and therefore had to be open to receive and listen to other groups that were without parliamentary representation but were nonetheless socially representative (Id., p. 17, paras. 1-2). Furthermore, the lehendakari suggested that the people who once belonged to the outlawed political party Batasuna should have the opportunity to become democrats and be part of Basque political institutions. ${ }^{21}$ Batasuna, previously known as Herri Batasuna (HB), was a Basque pro-independence and left-wing political party. Whereas Batasuna/HB shared ETA's radical ideological claim - the struggle to achieve a Basque socialist independent state - it was not involved in armed activity (although it also did not explicitly reject ETA's violence). Between 1977 and 1998, Batasuna/HB was an influential and controversial actor in Basque and Spanish politics. It held the second most number of seats in the Basque Parliament, had a large number of councilors in town councils in the Basque Country, and had parliamentary representation in Spain's Congress of Deputies as well as the European Parliament. ${ }^{22}$ Batasuna/HB represented a complex socio-political world, ${ }^{23}$ drawing together the radical Basque proindependence and left-wing groups (izquierda abertzale) as well as the Movimiento Vasco de Liberación Nacional (in English, Basque National Liberation Movement) [see also Bullain 2014, 470-477]. Aware of this, the lehendakari had specified that membership of the Working Group would only include groups with parliamentary

Therefore the party with an absolute majority - with more seats - in Congress will assure its candidate as the next president of the government. If not, political groups can negotiate to agree to vote for a candidate. This is regulated by articles 68 and 99 of the Spanish Constitution of 1978, and law on general elections regime, Ley Orgánica 3/2011.

21 Leading newspapers' modified the lehendakari's speech on 8 March 2012. See Europa Press (in 20 Minutos) 2012, EFE and Europa Press (in El Mundo) 2012, EFE (in ABC) 2012.

22 Participation of a party: Herri Batasuna ('HB' from 1977 to 1998 in general, autonomous, local and European elections), in Gobierno Vasco 2011c.

${ }^{23}$ I prefer to use the word world and not network since all abertzale groups shared ideology but not all were represented in Herri Batasuna. Some had their own parliamentary representation. 
representation. In a radio interview, Antonio Basagoiti, the leader of the Basque People's Party, said that the lehendakari and his government were 'proposing unattainable things (...) for example, a policy, which, I believe lacks firmness against what is called Batasuna' (Basagoiti 2012; author's translation). Subsequently, Basagoiti announced that the agreement with the Basque Socialist Party was broken (El Periódico 2012, Martínez 2012).

Nonetheless, on 30 March, 2012, the Basque Parliament approved the creation of the Working Group for Peace and Coexistence with the support of 70 out of 73 votes (Moción relativa a los proyectos de construcción conjunta de la paz y la convivencia 2012). While it was agreed that the Working Group would be open to socially representative groups - as the lehendakari proposed - a deal-breaker arose during negotiations regarding the 'permanent participation' of Basque radical proindependence left-wing groups. Aralar (the party that led the initiative to form a working group) demanded that the izquierda abertzale - now represented by the emergent nationalist political parties Bildu and Sortu, but without representation at the Basque Parliament - must be part of the Working Group. If the groups at the Basque Parliament did not agree to it, Aralar's four representatives threatened to vote against the constitution of the Working Group for Peace and Coexistence.

Aralar's demands were not met, and its leadership threatened to expel Ezenarro (who led the initiative of the Working Group in February 2012 before the lehendakari took over in March of the same year) and her fellow three members of Parliament, if they supported the creation of the Working Group. Ezenarro, Basabe and Erostarbe went against Aralar's orders and instead voted in favor of the Working Group. In consequence, Aralar expelled them, and the party was left with only one representative in the Basque Parliament (EI Correo 2012). The three votes against the creation of the Working Group came from Unión Progreso y Democracia (moderate), Ezker Batua-Berdeak (left-wing) and the only member left in Aralar.

In the following parliamentary session, tensions were evident and increased as political parties started pressing the lehendakari to call for early elections in the following months of 2012 instead of 2013 (Martínez 2012). With a discourse marked by the economic crisis and the new time opened since the 2011 ceasefire (El HuffPost and Agencias 2012) lehendakari López called for regional election to let citizens 'decide which political project must lead Euskadi' (Irekia 2012; author's translation). The Basque Nationalist Party declared they felt 'relieved' after 'the agony of a weak and disoriented government' (Agencias 2012), while the Basque People's Party said they 'deserve[d] to manage the end of ETA' (Europa Press 2012). And, from the izquierda abertzale, EH Bildu said only they proposed 'a change in-depth' (Alonso 2012).

In the midst of upcoming new elections, and with strained political relationships, the Working Group for Peace and Coexistence drafted the Basque Parliament's Ethical Minimum Agreement. This Agreement was a proposal to establish 'a peace with memory and without amnesia', to guide the terms of political and institutional conduct and engagement within the Basque Parliament (Sainz 2012). The following subsection describes how the Basque political parties and groups participated in the process of developing the Ethical Minimum Agreement and the Plan for Peace and Coexistence, and examines how the particular experience of the conflict of those groups and parties conditioned the success of the institutional initiatives.

\subsection{Two Political Documents: The Ethical Minimum Agreement and the Plan for} Peace and Coexistence

The 2012-2016 political term was to be one of new beginnings. Íñigo Urkullu, from the Basque Nationalist Party, became lehendakari, bringing the Basque National Party back to power after four years out of office (Gobierno Vasco 2011a). After the 2012 elections, the Basque People's Party and Basque Socialist Party lost parliamentary seats and began to experience a loss of political influence. Yet, the izquierda abertzale 
began a new journey in the Basque institutions. If a group experienced the force of working together, it was them. EH Bildu - a coalition of four pro-independence leftwing Basque parties, including Aralar and Eusko Alkartasuna - received $25 \%$ of the votes, and gained twenty-one representatives in the Basque Parliament (El País 2012).

In December 2012, the Basque Socialist Party presented a proposal to urge the Basque Parliament to debate and decide over the re-constitution of the Working Group on Peace and Coexistence, as a 'space built from the effort of different parties made to achieve consensus'. ${ }^{24}$ Before the socialists' proposal, the Basque People's Party presented an initiative requesting an institutional declaration to press for the dissolution of ETA, as well as a collective institutional rejection of its violent activity. The Basque People's Party proposal compelled the members of Parliament to make a common commitment to work together in the Working Group.

While the Basque People's Party proposal was rejected, all groups amended the socialists' proposal. ${ }^{25}$ Each group also proposed their own new foundational text, ${ }^{26}$ but these coincided at least on the need to continue the work of the previous Working Group with the creation of a new group, and to seek consensus and dialogue through the ethical grounds proposed in the past term. At the same time, each amendment showed a particular approach to the past. This seemed to reflect the relationship of each political group and party to the historical past, that is, how they remember it through their experience (Olick et al. 2011, 6-8). In other words, the amendments subtly reflected the different political positions based on the memory and historical experience of each group (I bid.). The groups' positions in the Parliament represented, to an extent, the collective yet divided relationship to the past, and their judgement of the root-causes and development of the Basque Case.

The Basque Socialist Party's text emphasized the unjust suffering of the past and victims' need for justice, collective memorialization, and reparation (I bid.). Their text also appealed to an institutional shared commitment to secure the non-repetition of violence based on an absolute ethical ground (Ibid.). The political party Unión, Progreso y Democracia (UPyD) focused in its text on ETA's disarmament, recognition of harm, and called judges to clarify ETA's crimes, while also demanding that ETA respect the victims' memory, justice and dignity (Ibid.). The Basque People's Party demanded ETA to condemn any acts of terrorism as a public commitment to show ETA accepted 'citizen amity based on plurality and the acceptance of democratic institutions' (Ibid.). The Basque Nationalist Party proposed a broad consensus to consolidate 'peace, humanization, and social reconciliation after a destructive conflict' (I bid.). EH Bildu, without making an express reference to ETA or terrorism, proposed the 'acknowledgement of all human rights violations which caused multiple suffering to base coexistence on truth, justice, and memory', and to 'work in collaboration with social agents involved in this field' (I bid.). The later proposal was as contentious, and as much of a deal-breaker, as it had been in the previous term.

In this context, the Basque Socialist Party and Basque Nationalist Party together presented an amendment, which was approved, to re-constitute the Working Group (EITB 2013a). This proposal was approved mainly through the votes of the Basque Socialist Party and the Basque Nationalist Party. The Basque People's Party and UPyD voted against it, while EH Bildu abstained. As a result, the Working Group was re-

\footnotetext{
${ }^{24}$ Full proposal presented by the Basque Socialist Party to the Board of the Basque Parliament on Dec. 4, 2012 and debated in the Basque Parliament on Feb. 14, 2013 (Debate monográfico sobre los pasos que se deben dar para la resolución del conflicto político [101108000003]).

${ }^{25}$ See, Basque People's Party proposal presented on 28 Nov. 2012: Quiroga 2012. For a full record of this proposal, see Relativa a la disolución definitiva e incondicional de ETA (2012).

${ }^{26}$ See, the different political group's amendments regarding the creation of a working group for peace and coexistence: En relación con la creación de una ponencia de paz y convivencia (10/11.02.01.0013) [author's translation].
} 
constituted with representatives of all political groups, except for members of the Basque People's Party and UPyD.

In March 2013, a special session was convened to debate the 'steps to resolve the Basque political conflict' and ratify the Ethical Minimum Agreement - the ethical grounds for political engagement proposed in 2011 by the Working Group (Debate monográfico 2013). This time, the Basque People's Party voted in favor, along with the Basque Socialist Party and Basque Nationalist Party, but not EH Bildu or UPyD. $\mathrm{EH}$ Bildu's spokesperson said that her group would continue to be part of the Working Group but the language used in the Ethical Minimum Agreement suggested a subjective narrative of the conflict (EFE 2013c), and that the Parliament had preferred to foster its relationship with the Basque People's Party while 'sacrificing' a closer relationship with EH Bildu (Elorza 2013). The Basque Parliament's president postponed the first meeting of the Working Group and appealed to mutual respect, after an intense debate, in which EH Bildu said all the victims were 'victims of a political cause', to which the Basque People's Party replied that EH Bildu were justifying ETA's crimes (EITB 2013b).

In June, the Basque Government presented a draft of the Plan for Peace and Coexistence as a proposal to parliamentary groups, civil society organizations and citizens. The draft received a total of twenty-eight contributions from different social and political groups, which, according to the Basque Government, reflected the plurality of concerns, pains, fears and expectations' of Basque society [Plan de Paz y Convivencia 2013-16 (Plan for Peace and Coexistence 2013-16), p. 11, para. 1]. In the attempt to reach an agreement, the Basque Socialist Party proposed to postpone the scheduled Working Group meeting so they could first read EH Bildu's contributions. EH Bildu and the Basque Nationalist Party opposed that motion, provoking the Basque Socialist Party to announce that they would leave the Working Group (EFE 2013a). Consequently, and 'without minimum conditions to work together', the Basque Nationalist Party also announced that they would leave the Working Group (Iturrate 2013).

The efforts and struggle of the different political groups and parties to engage with each other and work together on a shared institutional response to peaceful coexistence has set important and meaningful foundations for future institutional action. For example, although the Working Group for Peace and Coexistence has not resumed its activities since 2013 (Alzelai and Hernán 2017), in 2017 a new parliamentary space was created, the Working Group on Memory and Coexistence (Mancisidor 2017). Despite appeals to the Basque People's Party to participate, the party has repeatedly declined to join, being the only parliamentary group absent (Vega 2017). As for the Basque Government's 2013-2016 Plan for Peace and Coexistence, a series of institutional initiatives on the Basque Case's collective historical memory, peace education, victims and public participation were implemented. And now, the 2013-2016 Plan has been updated and entitled the Plan for Coexistence and Human Rights 2017-2020, embracing once again the Ethical Minimum Agreement as an ethical and democratic basis to work together (Plan de Convivencia y Derechos Humanos 2017-2020, 4 April 2017).

The history of these Basque political initiatives and documents shows how crucial it is to commit to, and take steps towards, developing a shared institutional response to the Basque Case. It shows how 'political reconciliation' is not only a deeply complex process, but also one that needs a plurality of political agents committed to work together.

\section{The Shape of Political Coexistence in the Basque Case}

In this final section, I examine how the institutional action of, and in, the Basque regional Government and Parliament shaped 'political coexistence' between 2011 and 2015. I do this in two steps. First, building on the history set out in part 2, I explain how the historical past of each political party and group has influenced their forms of 
political engagement or 'political coexistence' in (1) developing an institutional response to peaceful coexistence after ETA's 2011 announcement, and (2) crafting together the terms for political engagement within Basque political institutions. Second, I return to my analysis of the texts that form the Basque institutional action for peaceful coexistence: the Working Group for Peace and Coexistence, the Ethical Minimum Agreement, and the Plan for Peace and Coexistence. This analysis shows how 'political coexistence' was, and remains, fundamental to develop, shape and sustain an institutional and political response to peaceful coexistence in the Basque Country. Moreover, it shows how 'political coexistence' within Basque institutions is informed by political parties' and groups' different experiences, perspectives and positions on violence, pluralism, and agreement in the Basque Case.

\subsection{Analyzing the Influence of Historical Political Positions on the Basque Case}

The longevity of the conflict created intense feelings of enmity between political groups and entrenched polarized positions. The enmity perception between the different groups was intensified in the Basque Parliament, where the number of seats won in each election tends to reflect who is in a position of power and control. However, political groups in Basque political institutions do not only represent power and the interests of a specific social group, but also opposite historical positions.

The Basque Socialist Party and Basque People's Party are considered to represent Spain, as they are considered an extension of the Spanish Socialist Party and the People's Party, respectively. For that reason these parties are often accused of having a hidden agenda at the service of Spanish interests. The Basque Nationalist Party, for the decisive role it played in the creation of the symbols of the Basque institutional identity, is perceived as a strong defender of Basque interests. The political groups from the izquierda abertzale represent the world of the Basque labor struggle, influenced by traditional national liberation movements' ideologies. In this line, they were the first ones to develop a strategy to counter Franco's oppression in the Basque Country, and later engaged in the struggle to achieve independence from Spain through non-violent means without ever openly opposing violence. In this context, both the Basque Nationalist Party and the izquierda abertzale shared a spirit of autonomy from Spain. Yet, the izquierda abertzale has often seen the Basque Nationalist Party as a passive and weak agent in negotiations with the Spanish Government. That helps to explain why the Basque Nationalist Party's loss of control of the Basque Government between 2009 and 2012 was considered a lesson learnt for the Basque Nationalist Party because of its perceived ambivalence in addressing ETA's terrorism.

That experience encouraged the Basque Nationalist Party in 2012 to lead the institutional response to the 2011 ceasefire with more firmness, yet aware that collaboration with other political parties was crucial. However, the Basque Nationalist Party was in a complex position. On the one hand, as a group with strong ties to the institution-building process of the Basque nation (see, generally, Fusi 1984), they had to support political efforts of other nationalist groups such as the Lizarra Agreement, and sacrifice their relationship with the Basque Socialist Party (considered an extension of Spain). On the other hand, the Basque Nationalist Party never supported ETA's armed struggle or the izquierda abertzale's positions - the core of their ideology is far from left-wing movements. From a political-strategic perspective, the Basque Nationalist Party sees itself as a guardian of Basque interests from Madrid, through their representation at the Spanish Congress of Deputies, and its role in negotiating the Financial Agreement every five years (Gobierno Vasco n.d.). Therefore, the Basque Nationalist Party has had to be extremely careful in deciding not only their political alliances, but also the timing of their interventions.

Within the izquierda abertzale, the Basque People's Party tends to be seen as the political reincarnation of historical positions aimed at eradicating Basque identity and increasing administrative centralization in favor of the Spanish Government. Basque 
Socialists are also regarded as having enabled the death-squad GAL's perpetrations against Basques. At the same time, however, because of their ties to the People's Party and Spanish Socialist Party in the Spanish Congress of Deputies, these two parties are considered to have important influence in unblocking contentious points in the Basque Case (for example, Spain's prisons policy toward ETA prisoners, or decisions over negotiating the dismantling of ETA).

The historical and institutional influence of Basque political parties, briefly outlined here, is crucial to understand how different notions of 'political coexistence' are crafted in the Basque institutions. Thus, in the Basque case, the forms of political engagement in developing a shared institutional response tend to reflect a plurality - and at times opposing - positions on how to approach peaceful coexistence for the Basque Country.

4.2. Political Coexistence: Achievements and Challenges on Conceptions of Violence, Pluralism and Agreement

Aralar, the group representing the izquierda abertzale in the Basque Parliament in 2012, urged the Parliament to discuss specific projects to manage the new sociopolitical space opened after the 2011 ceasefire. Aralar's initiative is especially relevant. On the one hand, it reflects the intention of 'radical Basque left-wing separatist' groups to institutionalize their willingness to publicly discuss a series of political initiatives to build peace with other groups (the Basque Nationalist Party, Basque Socialist Party, Basque People's Party) that have been contesting the Basque Case for decades within political institutions. The institutionalization of the izquierda abertzale's political intentions occurred when the Basque Socialist Party and Basque People's Party had signed their coalition agreement (the Grounds For Democratic Change) allowing them, for the first time, to be in key positions of power in the Basque Government and Basque Parliament.

The fact that the Basque Nationalist Party was not in government opened a space and gave an opportunity to the izquierda abertzale to clarify their own institutional position in this new period, without the usual prior negotiations with the Basque Nationalist Party. It was the socialist lehendakari López who, in the name of the Basque Government, named Aralar's proposal as a Working Group of Peace and Coexistence in March 2012. Yet, the lehendakari's initiative was built on the document that Aralar - as the only institutional representative of the izquierda abertzale - used to propose the creation of the Working Group in February 2012. That document symbolized that all groups with parliamentary representation could contest and seek collective decisions on political coexistence after a long cycle of violence. More than that, it set a precedent for possible ways to work together while acknowledging the plurality of political sensibilities they all represented. The decision of Aralar's parliamentarians to break with their party's discipline might suggest that there is a group within the izquierda abertzale that is open to developing basic yet common positions on the violent past, and that is committed to work with its 'others'.

Although EH Bildu (in which Aralar was represented after 2012) became part of the 2013 Working Group, the abstention of all its parliamentarians from voting for the Working Group's re-constitution suggests that there is a sector within the izquierda abertzale that is open to dialogue but remains strongly skeptical. This can be seen from EH Bildu's votes against the ratification of the Ethical Minimum Agreement text in 2013.

As discussed in the previous part, the Ethical Minimum Agreement was drafted by the members of the Working Group in 2012, and ratified in the Basque Parliament in 2013. The text is an agreement to establish an 'ethical ground' on 'principles of peace with memory' (Plan de Paz y Convivencia 2013-16, p. 84). The Basque Government incorporated the Ethical Minimum Agreement as the framework for interpreting the 2013-2016 Plan for Peace and Coexistence. However, the Basque Government, aware that the state of political relationships or 'political coexistence' in the Basque 
Parliament would create difficulties for the approval of future institutional peacebuilding policy, decided to draft the Plan for Peace and Coexistence as a governmental document, which would not require the approval of the Basque Parliament.

A close reading of the Plan for Peace and Coexistence and the Ethical Minimum Agreement, informed by an understanding of the context in which the Working Group for Peace and Coexistence developed, suggests that notions of 'violence', 'pluralism' and 'agreement' shape how 'political coexistence' is fundamental to the development of an institutional and political response to peaceful coexistence in the Basque Country. The remaining part of this section analyzes the achievements and challenges of these conceptions of 'violence', 'pluralism' and 'agreement' within Basque political institutions. ${ }^{27}$

\section{(i) Violence}

The word violence ('violencia') is repeated approximately twenty times in the Ethical Minimum Agreement, and it is used to describe a source of irreparable pain, human rights violation, tension, fear and division. Although 'violence' is used more times in the Plan for Peace and Coexistence than in the Ethical Minimum Agreement, in the latter it is understood as the root cause of destruction and a 'useless' means to address conflict. This suggests that conflict in the Ethical Minimum Agreement is perceived as part of political interaction, but can be managed only through nonviolent means.

The Basque Government in the Plan for Peace and Coexistence 2013-16 shows its willingness to put an end to the era of mistrust and suspicion created by past violence. For this reason, the Basque Government invited the political groups in the Basque Parliament to submit feedback on the Plan. This sent the signal that the Government was committed to genuine collaboration. Furthermore, the Basque Government incorporated the Ethical Minimum within the Plan for Peace framework of interpretation. In this way, the Basque Government joined the commitment of the groups in the Basque Parliament to develop together an institutional action, on shared ethical grounds, that publicly rejected violence as something that cannot be justified in any circumstance. Nevertheless, the Plan for Peace emphasized the need to differentiate the sources of violence in each socio-political context. The Plan for Peace text is sensitive to mixing victims of different sources of violence, and thereby clarifies that ETA victims require a specific assessment.

\section{(ii) Pluralism}

The Ethical Minimum Agreement was the outcome of the Working Group's efforts to draft a common ethical ground on which all political parties and groups could stand, and the Basque Government's openness to receive and modify the Plan for Peace after the contributions of political groups, civil society organizations and citizens. This shows that both texts are clearly inspired by the plural condition of political and social life that characterizes Basque society.

The Ethical Minimum Agreement text has many references to seeking 'common' positions on memory, truth, and victims. There is also a constant appeal to work together to create shared spaces where the diverse historical, ideological and political sensitivities in Basque society can coexist. The Plan for Peace characterizes shared spaces as public squares, and the Basque Government currently implements this idea through the Plaza de la Memoria (in English, Public Square of Memory; see also Gogora n.d.), as a tool to institutionalize the progressive development of a Basque collective memory.

27 This part of the research was conducted through a close reading of the texts and analyzed in light of the historical and current socio-political context. The three codebooks developed for this analysis are on file with the author, and are available upon request, or through the Library of the International Institute for the Sociology of Law. See, Vázquez Guevara 2015. 


\section{(iii) Agreement}

The plural condition of Basque society, along with the accentuated divisions caused by the historical violence, requires the inclusion of the main groups representing the divergent positions. The importance of dialogue and listening to different points of views are essential to build a world together despite the differences. Agreement is also perceived as a goal to work towards. To this end, both the Ethical Minimum and Plan for Peace show the strategic importance of education for the Basque Parliament and Government. The Ethical Minimum highlights that through education a 'consensus seeking' spirit could be transmitted to, and instilled in, future generations. This approach is in line with the Plan for Peace's goals. For example, the Basque Government emphasizes the number of meetings held with the educational sector on education for peace and coexistence. Currently there are human rights programs designed in the Plan for Peace and implemented in schools in Basque Country.

The Plan for Peace also seeks to achieve consensus through a subtle mechanism called 'micro-agreement'. In part this reflects the challenge of achieving grand displays of consensus, as well as the wariness of the expectations that they might generate. Instead, the Basque Government has chosen to be flexible and pursue small agreements on specific issues.

These notions of 'violence', 'pluralism' and 'agreement' have a two-fold role in shaping 'political coexistence' in the Basque Case. On the one hand, they have the potential to accentuate the historical and socio-political divisions amongst Basque political groups and institutions (as demonstrated by the refusal of the Basque People's Party to take part in the Working Group). The refusal to participate has the potential to obstruct a plurality of groups to develop shared terms for political engagement within political institutions. On the other hand, these terms of engagement have the potential to bring a plurality of political agents together, to engage with each other in shaping their collective understandings. In sum, it is important that a plurality of groups work together to develop shared terms of political engagement and notions of 'coexistence' for the Basque Case.

\section{Conclusion}

As J esús Eguiguren, the Spanish Government's lead negotiator with ETA in 2006, said in 2017: 'The end of ETA has been the outcome of many things' (González Egaña 2017). This article has focused on one of these many things that contributed to the consolidation of a new time of peace and coexistence in the Basque Country: the institutional action of, and in, the Basque regional Government and Parliament in the aftermath of ETA's 2011 ceasefire announcement.

The outcome of the institutional action of these Basque political institutions was the institutional initiative, the Working Group for Peace and Coexistence, and the two political documents discussed in this article, the Ethical Minimum Agreement and the Plan for Peace and Coexistence. Yet it has been the institutional action in the Basque Government and Parliament that made these outcomes possible.

This form of political engagement shaped the prospects of 'political coexistence' within Basque political institutions, as well as the pluralistic nature of their institutional action. In other words, the institutional action - with all its complexity, challenges and obstacles - undertaken by and in Basque political institutions has started the process of 'political coexistence'. Such an outcome, as shown through this article, has to be understood as a constant process of renegotiating the terms of engagement of a plurality of political groups within political institutions after violent conflict.

In contexts of transition to more peaceful, or less violent, socio-political engagements, law and institutions play a crucial role in openning spaces to renegotiate the meaning of individual and collective life in a society. Otherwise the past's violent legacy has the potential to blend with the emerging new conflicts that 
political life itself entails. This article has outlined the importance of the legal and political action of the state and its institutions in addressing, and securing, the termination of violent conflict, and hence in setting the foundation for political coexistence. The argument running through this article is that 'political coexistence' in the Basque Case depends not only on including emergent political groups, composed of people with a 'past', but also those whose present actions express a commitment to the incipient ethical foundations instituted in the Ethical Minimum Agreement. At the same time, it is essential for these groups to accept the existence of each other's ideologies, feelings, and experiences of the conflict. This form of political engagement or 'political coexistence' has the potential to open spaces and acknowledge the value - under ethical minimums - of the positions of 'the other'.

\section{References}

Agencias, 2004. Batasuna dice que sólo usará vías "políticas y democráticas" pero no pide a ETA que abandone las armas. El Mundo [online], 15 November. Available from: http://www.elmundo.es/elmundo/2004/11/14/espana/1100450849.html [Accessed 26 July 2018].

Agencias, 2011. Rajoy promete en su programa electoral "no negociar con terroristas". El Mundo [online], 30 October. Available from: http://www.elmundo.es/elmundo/2011/10/30/espana/1319969066.html [Accessed 26 July 2018].

Agencias, 2012. El PNV, "aliviado" por el "final de la agonía" de un Gobierno "débil". El Mundo [online], 21 August. Available from: http://www.elmundo.es/elmundo/2012/08/21/espana/1345551235.html [Accessed 26 July 2018].

Alonso, J.M., 2012. Mintegi: "Sólo EH Bildu ofrece el cambio en profundidad que Euskadi necesita". El Mundo [online], 22 August. Available from: http://www. elmundo.es/elmundo/2012/08/22/paisvasco/1345631571.html [Accessed 26 July 2018].

Alzelai, N., and Hernán, A., 2017. El año del desbloqueo. Naiz [online], 27 December. Available from: https://www. naiz. eus/es/hemeroteca/gara/editions/2017-1227/hemeroteca_articles/el-ano-del-desbloqueo [Accessed 26 J uly 2018].

Arendt, H., 1998. The Human Condition. University of Chicago Press.

Basagoiti, A., 2012. Basagoiti da por "agotado" el pacto con el PSE en Euskadi y plantea elecciones anticipadas. [Audio recording of interview on Punto Radio Euskadi]. Diario Vasco [online], 7 May. Available from: https://www. diariovasco.com/multimedia/audios/ultimos/2211878-basagoitiagotado-pacto-euskadi-plantea-elecciones-anticipadas.html [Accessed 26 J uly 2018].

BBC News, 2010. Basque separatist group Eta "declares ceasefire". BBC [online], 5 September. Available from: https://www.bbc.co.uk/news/world-europe11191395 [Accessed 26 July 2018].

BBC News, 2011. Full text: Basque ceasefire declaration. BBC [online], 20 October. Available from: http://www.bbc.com/news/world-europe-15395157[Accessed 26 July 2018].

Bengoetxea, J., 2013. Transitional Justice versus Traditional Justice: The Basque Case. Journal on Ethnopolitics and Minority Issues in Europe [online], 12 (2), 30-58. Available from: http://www.ecmi.de/fileadmin/downloads/publications/JEMIE/2012/Quer.pdf [Accessed 26 July 2018]. 
Bullain, I., 2014. Aproximación a la Violencia Política en el País Vasco y Perspectivas de una Justicia Restaurativa para Euskadi. Oñati Socio-legal Series [online], 4 (3), 465-506. Available from: http://ssrn.com/abstract=2363899 [Accessed 26 July 2018].

Burridge. T., 2013. Spain dispute over Eta militant's early release from jail. BBC [online], 25 October. Available from: http://www.bbc.com/news/worldeurope-24653851 [Accessed 26 July 2018].

Churchill, B., 2013. Chapter 11: Content Analysis. In: M. Walter, ed., Social Research Methods. $3^{\text {rd }}$ ed. Oxford University Press, 255.

Comparecencia del lehendakari para valorar el acuerdo mayoritario alcanzado el día 21 de febrero de 2012 en el Congreso de los Diputados sobre la gestión del final de ETA y proponer medidas acordes al nuevo tiempo. Diario de Sesiones del Parlamento Vasco [online], № 139, 8 March 2012. Available from: http://www. legebiltzarra.eus/ic2/restAPI/pvgune_descargar/default/4868deb9 -0ca0-448d-82a9-563e9f6812c5 [Accessed 26 July 2018].

Conciliation Resources, 2009. Accord: Striking a Balance: The Northern I reland Peace Process [online]. London. Available from: http://www.cr. org/downloads/08 Northern_Ireland.pdf [Accessed 26 July 2018].

Cruz, M.C., 2015. El PNV y Amaiur piden cambiar la política de presos a Rajoy que insiste en la disolución de ETA. RTVE [online], 25 February. Available from: http://www.rtve.es/noticias/20150225/pnv-amaiur-piden-cambiar-politicapenitenciaria-rajoy-insiste-disolucion-eta/1104441.shtml [Accessed 26 J uly 2018].

Czarnota, A., 2001. Law as Mnemosyne and as Lethe: Quasi-judicial institutions. In: E. Christodoulidis and S. Veitch, eds., Lethe's Law: Justice, Law and Ethics in Reconciliation. Oxford / Portland, OR: Hart.

Debate monográfico sobre los pasos que se deben dar para la resolución del conflicto político [101108000003]. Diario de Sesiones del Parlamento Vasco [online], no 21, 3-56. 22 March 2013. Available from:

http://www.legebiltzarra.eus/ic2/restAPI/pvgune_descargar/default/ae48cd72 -0185-4c10-b1dd-3254dde5d1fc [Accessed 26 July 2018].

Debate y resolución definitiva de la proposición no de ley formulada por el grupo parlamentario Socialistas Vascos, en relación con la creación de una ponencia de paz y convivencia. Diario de Sesiones del Parlamento Vasco [online], no 10, of 14 February 2013. Available from:

http://www.legebiltzarra.eus/ords/f?p=CTP: ASUNTOS DETALLE: 1065552349 07340: : NO: RP:P10_ID: 118309 [Accessed 26 July 2018].

Derrida, J., 1992. Force of Law: The Mystical Foundation of Authority. In: D. Cornell, M. Rosenfeld and D. Carlson, eds., Deconstruction and the Possibility of Justice. New York / London: Routledge.

Domaika, E., 2015. Un memorial de campaña [text and audio recording]. SER Euskadi [online], 23 March. Available from:

http://cadenaser.com/emisora/2015/03/23/radio_bilbao/1427095475_568988 html [Accessed 26 July 2018].

EFE (in ABC), 2012. Patxi López reclama un partido legal para Batasuna y su entorno. ABC [online], 8 March. Available from: https://www.abc.es/20120308/espana/abci-patxi-lopez-201203081128.html [Accessed 26 July 2018].

EFE and Europa Press (in El Mundo), 2012. López critica a quien pone obstáculos a Batasuna en su paso a la democracia. El Mundo [online], 12 March. Available from: 
http://www. elmundo.es/elmundo/2012/03/12/paisvasco/1331541789.html [Accessed 26 July 2018].

EFE, 2013a. EI PSE no acudirá a la ponencia vasca de paz por la "involución" de EH Bildu. Eldiario.es [online], 11 September. Available from:

https://www. eldiario.es/politica/PSE-ponencia-involucion-EHBildu_0_174282753.html [Accessed 13 August 2018].

EFE, 2013b. Carlos Urquijo: En el País Vasco no hay ningún proceso de paz en marcha. El Mundo [online], 26 October. Available from: http://www. elmundo.es/elmundo/2013/10/26/paisvasco/1382779539.html [Accessed 26 July 2018].

EFE, 2013c. La ponencia de paz acuerda partir de un suelo ético sin el apoyo de EH Bildu. Diario Vasco [online], 14 May. Available from:

https://www. diariovasco.com/20130513/mas-actualidad/politica/ponenciaacuerda-partir-suelo-201305131311.html [Accessed 26 July 2018].

EFE, 2015. PNV, PSE y EH Bildu critican que Rajoy no cuente con Urkullu para el Memorial de Víctimas. El Correo [online], 21 March. Available from:

https://www. elcorreo.com/bizkaia/politica/201503/21/bildu-critican-rajoycuente-20150321162514.html [Accessed 7 September 2018]

EITB, 2011. Patxi López: "La sociedad vasca ha cumplido su sueño" [text and video recording]. EiTB [online], 21 October. Available from:

https://www. eitb.eus/es/noticias/politica/detalle/760649/patxi-lopez-lasociedad-vasca-ha-cumplido-su-sueno/ [Accessed 26 J uly 2018].

EITB, 2013a. EI PNV y el PSE crearán la ponencia de paz sin el PP. EiTB [online], 13 February. Available from:

https://www. eitb.eus/es/noticias/politica/detalle/1257254/ponencia-paz--pnvpse-crearan-ponencia-pp-/ [Accessed 13 August 2018].

EITB, 2013b. Pospuesta la Ponencia de Paz tras una bronca entre PP y EH Bildu [YouTube clip]. EiTB [online], 15 March. Available from: https://www. youtube.com/watch?v=SbL8] AkuP-A [Accessed 26 July 2018].

El Correo, 2012. Aralar expulsa a Ezenarro, Basabe y Erostarbe. El Correo [online], 7 May. Available from: https://www.elcorreo.com/alava/20120507/masactualidad/politica/aralar-expulsa-parlamentarios-ezenarro201205072042.html [Accessed 26 July 2018].

El HuffPost and Agencias, 2012. Patxi López adelanta las elecciones autonómicas vascas al 21 de octubre. Huffington Post [online], 21 August, updated 20 October. Available from: https://www. huffingtonpost.es/2012/08/21/patxilopez-adelanta-las-elecciones-autonomicas-vascas-21octubre_n_1815944.html [Accessed 26 July 2018].

El País, 2012. Elecciones autonómicas 2012. País Vasco. El País [online], September. Available from: https://resultados. elpais.com/elecciones/2012/autonomicas/14/ [Accessed 26 July 2018].

El Periódico, 2012. Basagoiti da por terminado el pacto con el PSE y pide adelantar las elecciones en Euskadi. El Periódico [online], 7 May. Available from: https://www. elperiodico.com/es/politica/20120507/basagoiti-da-porterminado-el-pacto-con-el-pse-1754822 [Accessed 26 July 2018].

Elorza, A., 2013. El Parlamento ratifica el "suelo ético" sobre el que forjar la paz y la convivencia. El País [online], 22 March. Available from: https://elpais.com/ccaa/2013/03/22/paisvasco/1363967004_809492.html [Accessed 26 July 2018 ]. 
En relación con la creación de una ponencia de paz y convivencia (Enmiendas)

(10/11.02.01.0013). Boletín Oficial del Parlamento Vasco [online], no 8, of 11 January 2013, p. 222. Available from:

http://www.legebiltzarra.eus/ords/f? $p=120: 21: 106253302417821:$ : NO: RP,RI R:P21_ID:46478 [Accessed 26 July 2018].

Europa Press (in 20 minutos), 2012. López propone una ponencia parlamentaria de paz y convivencia "abierta a personas y organismos" ajenos a la Cámara. 20 minutos [online], 8 March. Available from: https://www. 20minutos.es/noticia/1331960/0/ [Accessed 26 J uly 2018].

Europa Press, 2011. Basagoiti considera el comunicado de ETA una "buena noticia". Eldiario.es [online], 20 October. Available from:

https://www.eldiario.es/canariasahora/nacional/Basagoiti-consideracomunicado-ETA-noticia_0_269824314.html [Accessed 26 July 2018].

Europa Press, 2012. Basagoiti: "EI PP merece gestionar el final de ETA". ABC [online], 9 September. Available from:

https://sevilla.abc.es/20120909/espana/rc-basagoiti-merece-gestionar-final201209091331.html [Accessed 26 July 2018].

Europa Press, 2015. EH Bildu acusa a Rajoy de "despreciar a cientos de víctimas provocadas por la violencia de los aparatos del Estado". Eldiario.es [online], 24 March. Available from: https://www.eldiario.es/norte/euskadi/EH-BilduRajoy-despreciar-provocadas 0 369913204.html [Accessed 7 September 2018].

Euskal Kultur Erakundea / Institute Culturel Basque, n.d. Northern Basque Country or I parralde [online]. Uztaritze: Basque Culture Institute. Available from: https://www. eke.eus/en/kultura/basque-country/northern-basque-country-oriparralde [Accessed 26 July 2018].

Euskobarómetro, 2011. Euskobarómetro. Estudio periódico de la opinión pública vasca. Noviembre 2011 [online]. Bilbao: Euskobarómetro. Available from: https://www. ehu.eus/documents/1457190/1525260/EB1111.pdf [Accessed 26 July 2018].

Euskobarómetro, 2014. Euskobarómetro. Estudio periódico de la opinión pública vasca. Noviembre 2014 [online]. Bilbao: Euskobarómetro. Available from: https://www. ehu. eus/documents/1457190/1525260/Euskobarometro+Noviem bre+2014 [Accessed 26 July 2018].

Euskobarómetro, 2015. Euskobarómetro. Estudio periódico de la opinión pública vasca. Mayo 2015 [online]. Bilbao: Euskobarómetro. Available from: https://www.ehu.eus/documents/1457190/1525260/EB_Mayo15.pdf [Accessed 26 July 2018].

Ezeizabarrena, X., 2013. The Basque Issue and the Spanish Rule of Law: Report on the UPV/EHU “Última Ratio" Seminar. Oñati Socio-legal Series [online], 3 (1), 154-160. Available from: http://ssrn. com/abstract=2200887 [Accessed 26 July 2018].

Ezenarro, A., 2012. Moción consecuencia de interpelación [online]. Motion. VitoriaGasteiz: Parlamento Vasco. Available from: http://www.legebiltzarra.eus/ic2/restAPI/pvgune descargar/default/ee042236 -4c0b-497c-bc79-b6fa51ce501d [Accessed 26 July 2018].

Fusi, J., 1984. The Basque Question: 1931-7. In: P. Preston, ed., 2002, Revolution and War in Spain: 1931-1939. London: Routledge.

Gobierno Vasco, 2011a. Análisis comparativos. In: Archivo resultados electorales [online]. Available from: 
http://www.euskadi. eus/q93TodoWar/elecciones] SP/q93Contenedor.jsp?idiom a=c\&menu=li_2_1_3\&opcion=menu [Accessed 26 July 2018].

Gobierno Vasco, 2011b. Archivo de Resultados Electorales [online]. Available from: https://tinyurl.com/yacga34k [Accessed 26 July 2018].

Gobierno Vasco, 2011c. Participación de un partido. In: Archivo de resultados electorales [online]. Available from:

http://www. euskadi.eus/q93TodoWar/elecciones] SP/q93Contenedor.jsp?idiom a=c\&menu=li_2_1_6\&opcion=menu [Accessed 26 J uly 2018].

Gobierno Vasco, n.d. Concierto Económico [online]. Departamento de Hacienda y Economía-Gobierno Vasco. Available from: http://www.euskadi.eus/gobiernovasco/concierto-economico/inicio/ [Accessed 26 July 2018].

Gogora, n.d. Memoria plaza: Aurkezpena [online]. Bilbao: Gobierno Vasco / Gogora Institute for Remembrance, Coexistence and Human Rights. Available from: http://www.gogora.euskadi.eus/memoria-plaza/-/memoria-plaza-aurkezpena/ [Accessed 26 July 2018].

González Egaña, 2017. Jesús Eguiguren (Expresidente del PSE-EE): “El acto del desarme no puede convertirse en una especie de reconocimiento de lo que fue ETA". Diario Vasco [online], 26 March. Available from: https://www. diariovasco.com/politica/201703/26/jesus-eguigurenexpresidente-acto-20170326004127-v.html [Accessed 26 J uly 2018].

Govan, F., 2011. Spain election: Conservatives win landslide victory but new PM warns "there will be no miracles". The Telegraph [online], 20 November. Available from:

https://www.telegraph.co.uk/news/worldnews/ europe/spain/8903241/Spainelection-Conservatives-win-landslide-victory-but-new-PM-warns-there-will-beno-miracles.html [Accessed 26 July 2018].

Informe de la Comisión de Expertos para la definición del Centro Memorial de las Víctimas del Terrorismo, 2015 [online]. Madrid: Ministerio del Interior del Gobierno de España. Available from: http://www.interior.gob.es/prensa/noticias/lasset_publisher/GHU8Ap6ztgsg/content/id/3347168 [Accessed 26 J uly 2018].

I rekia, 2012. El Lehendakari convoca elecciones para el 21 de octubre [online]. Press release. Gobierno Vasco, 21 August. Available from: https://www.irekia. euskadi. eus/es/news/12026-lehendakari-convocaelecciones-para-octubre [Accessed 26 July 2018].

Iturrate, I., 2013. PNV: "No se dan condiciones para Ponencia Paz" [YouTube clip]. Europa Press [online], 11 September. Available from: https://www. youtube.com/watch?v=taw5jLmnQsg [Accessed 26 July 2018].

La Moncloa. 2015. Speech by President of the Government at inaugural event for Victims of Terrorism Memorial Centre [online]. Vitoria, 24 March. Available from:

http://www.lamoncloa.gob.es/lang/en/presidente/intervenciones/paginas/201 5/20150324-victims-of-terro. aspx/ [Accessed 26 July 2018].

Mancisidor Artaraz, E., 2017. Ponencia sobre Memoria y Convivencia en Euskadi [online]. Comisión de Derechos Humanos e Igualdad del Gobierno Vasco, 30 May. Available from: http://www.legebiltzarra.eus/pdfs_egutegi/20170607/9212.pdf [Accessed 26 July 2018].

Martínez, I.C., 2012. Basagoiti elige a Otegi y Batasuna para su primer choque con López. El País [online], 19 May. Available from: 
https://elpais.com/ccaa/2012/05/18/paisvasco/1337368174_667040.html [Accessed 26 July 2018].

Ministerio del Interior y Departamento de Interior del Gobierno Vasco, 2012. Protocolo de colaboración para la Creación del Centro Memorial para las Víctimas del Terrorismo [online]. Press release. Leioa, 24 January. Available from: http://www.interior.gob.es/file/54/54128/54128.pdf [Accessed 26 ] uly 2018].

Moción relativa a los proyectos de construcción conjunta de la paz y la convivencia, 2012. Diario de Sesiones del Parlamento Vasco [online], no 144, 30 March 2012, 2-28. Available from: http://www. legebiltzarra.eus/ic2/restAPI/pvgune descargar/default/ee042236 -4c0b-497c-bc79-b6fa51ce501d [Accessed 26 July 2018].

Montesinos, P., 2013. Rajoy aclara a Amaiur que 'el cumplimiento de la ley no se negocia'. Libertad Digital [online], 20 March. Available from: http://www.libertaddigital.com/espana/politica/2013-03-20/rajoyaclara-a-amaiur-que-el-cumplimiento-de-la-ley-no-se-negocia-1276485343/ [Accessed 26 July 2018].

Negroponte, D.V., 2012. Seeking Peace in El Salvador: The Struggle to Reconstruct a Nation at the End of the Cold War. New York: Palgrave Macmillan.

Olick, J.K., Vinitzky-Seroussi, V., and Levy, L., eds, 2011. The Collective Memory Reader. New York: Oxford University Press.

Ollivier-Maurel, P., and Davo, H., 2013. Facing Terrorism in the Field: The FrancoSpanish Experience [online]. Barcelona: Criminal J ustice Programme and European Commission, 6-7 February. Available from: https://ejustice. europa. eu/fileDownload. do?id=bf36f698-42df-4175-91b60d9dd5c5dcf0 [Accessed 26 July 2018].

Ormazabal, M., 2011. Batasuna asegura que el fin de ETA "no supone el cierre del conflicto". El País [online], 21 October. Available from: https://elpais.com/politica/2011/10/21/actualidad/1319192913_631702.html [Accessed 26 July 2018].

PSE-EE (PSOE) and PP-PV, 2009. Bases para el cambio democrático al servicio de la sociedad vasca [online]. Madrid: PSOE. Available from: http://web.psoe.es/izquierdasocialista/docs/279408/page/bases-para-cambiodemocratico-servicio-la-sociedad-vasca.html [Accessed 26 J uly 2018].

Quiroga, A., 2012. Proposición no de ley para debate en Pleno, relativa a la disolución definitiva e incondicional de ETA [online]. Vitoria-Gasteiz: Parlamento Vasco, 28 November. Available from: http://www. legebiltzarra. eus/ords/f?p=120: 18: $114417239064923:$ : NO: RP, 18 :P18 ID: 42309 [Accessed 26 July 2018].

Quiroga, A., 2015. Arantza Quiroga cree que Iñigo Urkullu recurre a la "pose" [interview on Radio Euskadi-Boulevard]. EiTB [online], 25 March. Available from: https://www. eitb.eus/es/radio/radioeuskadi/programas/boulevard/audios/detalle/3084476/centro-memorialvictimas-quiroga-cree-urkullu-recurre-pose/ [Accessed 26 July 2018].

Rajoy, M., 2011. Mariano Rajoy sobre el comunicado de ETA [YouTube clip]. partidopopular [online], 21 October. Available from: https://www. youtube.com/watch?v=AJ a5KJ SIvQg [Accessed 26 J uly 2018].

Relativa a la disolución definitiva e incondicional de ETA. Proposición no de ley

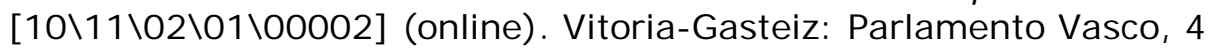
December 2012. Available from: 
http://www. legebiltzarra. eus/ords/f?p=120: 18: 114417239064923: : NO: RP, 18 :P18_ID: 42309 [Accessed 26 July 2018].

Rodríguez Zapatero, J.L., 2011. Declaracion [sic] Zapatero sobre el fin de ETA [YouTube clip]. Electronicwhispers [online], 20 October. Available from: https://www. youtube. com/watch? $v=$ XmOBF30300 [Accessed 26 July 2018].

RTVE, 2011. Zapatero: El comunicado de ETA “no sirve" y el Gobierno no va a permitir "ningún engaño". RTVE [online], 10 January. Available from: http://www.rtve.es/noticias/20110110/zapatero-dice-eta-comunicado-nosirve-gobierno-no-va-permitir-ningun-engano/394118.shtml [Accessed 26 J uly 2018].

Sainz, J., 2012. La ponencia de convivencia acuerda las bases para una "paz con memoria y sin amnesias". Diario Vasco [online], 14 July. Available from: https://www. diariovasco.com/20120713/mas-actualidad/politica/ponenciaconvivencia-acuerda-bases-201207131154.html [Accessed 26 July 2018].

Schaap, A., 2005. Political Reconciliation. London / New York: Routledge.

Segovia, M., 2015. Una grieta de Estado. El Mundo [online], 26 February. Available from: http://www.elmundo.es/paisvasco/2015/02/26/54eef18bca47410f588b4571.html [Accessed 26 J uly 2018].

Tremlett, G., 2006. Eta declares permanent ceasefire. The Guardian [online], 23 March. Available from: http://www. theguardian.com/world/2006/ETAceasefire [Accessed 26 July 2018].

Uriarte, J.M., 2013. La reconciliación. Santander: Sal Terrae.

Urkullu, I., 2011. Valoración cese definitivo de ETA [online]. Available from: https://www.eaj-pnv.eus/documentos/valoracian-cese-definitivoeta_9902.html [Accessed 26 July 2018].

Vázquez Guevara, V., 2015. Reconciliation in the Basque case: will they live happily ever after? Master's thesis, Sociology of Law. Oñati: International Institute for the Sociology of Law.

Vega, M., 2017. El PP rechaza las presiones para entrar en la Ponencia de Memoria y Convivencia. El Mundo [online], 15 October. Available from: http://www.elmundo.es/paisvasco/2017/10/15/59e32890468aeb273d8b4668.html [Accessed 26 J uly 2018].

Whitfield, T., 2014. Endgame for ETA: Elusive Peace in the Basque Country. New York: Oxford University Press.

Whitfield, T., 2015. The Basque Conflict and ETA: The difficulties of an ending. Special Report 384 [online]. Washington, DC: United States Institute of Peace. December. Available from: http://cic.nyu.edu/sites/default/files/whitfield_basque_conflict_eta_dec2015.p df

Wilson, R.A., 2001. The Politics of Truth and Reconciliation in South Africa: Legitimizing the Post-Apartheid State. Cambridge University Press.

\section{Legal sources}

Ley 29/2011, de 22 de Septiembre de Reconocimiento y Protección Integral a las víctimas de terrorismo. Boletín Oficial del Estado [online], o 229, of 23 September 2011. Available from: https://www. boe.es/boe/dias/2011/09/23/pdfs/BOE-A-2011-15039.pdf [Accessed 26 July 2018]. 
Ley 4/2014, de 27 de noviembre, de creación del Instituto de la Memoria, la Convivencia y los Derechos Humanos. Boletín Oficial del País Vasco [online], no 230, of 2 December 2014. Available from:

http://www.gogora.euskadi.eus/contenidos/informacion/gogora normativa/es def/adjuntos/ley4-2014-gogora-es.pdf [Accessed 26 July 2018].

Ley Orgánica 3/1979, de 18 de diciembre, de Estatuto de Autonomía para el País Vasco. Boletín Oficial del Estado [online], № 306, of 22 December 1979, 29357-29363. Available from:

https://www. boe.es/boe/dias/1979/12/22/pdfs/A29357-29363.pdf [Accessed 26 July 2018].

Ley Orgánica 3/2011, de 28 de Enero, por la que se modifica la Ley Orgánica 5/1985 del Régimen Electoral General. Boletín Oficial del Estado [online], no 25, of 29 January 2011 . Available from: https://www. boe.es/boe/dias/2011/01/29/pdfs/BOE-A-2011-1639.pdf [Accessed 26 July 2018].

The Spanish Constitution, 1978 [online]. Available from: http://www.congreso.es/constitucion/ficheros/c78/cons_ingl.pdf [Accessed 26 July 2018].

\section{Political documents}

Plan de Convivencia y Derechos Humanos 2017-2020. Un objetivo de encuentro social, la opción por la empatía [online]. Proposal. Secretaría General para la Paz y la Convivencia - Gobierno Vasco, 4 April 2017. Available from: https://www.irekia. euskadi. eus/uploads/attachments/9389/Plan_de_Conviven cia_y_DDHH_.pdf [Accessed 26 J uly 2018].

Plan de Paz y Convivencia 2013-16. Un objetivo de encuentro social [online]. Secretaría General para la Paz y la Convivencia - Gobierno Vasco, November 2013. Available from:

http://www.euskadi.eus/contenidos/plan_gubernamental/xleg_plangub_01/es plang_01/adjuntos/Plan\%20de\%20Paz\% 20y\%20Convivencia.\%20Envio\%20 al\%20Parlamento.pdf [Accessed 26 July 2018].

Texto del denominado Suelo Ético aprobado por el Parlamento Vasco [online]. Secretaría General para la Paz y la Convivencia - Gobierno Vasco, November 2013. Available from:

http://www.euskadi.eus/contenidos/informacion/dig_publicaciones innovacion Les_conviven/adjuntos/600019c_Pub_El_Bake_bizikidetza_plana_c.pdf

[Accessed 13 August 2018]. 